\title{
Challenge and Revelation Massive Open Online Course Brings to the British and American Literature Teaching
}

\author{
XU Li-mei, TONG Li-jun \\ Changchun University, Changchun, China
}

\begin{abstract}
Massive Open Online Course (MOOC) has many characteristics, such as mass, openness, and online learning, which can effectively make up for the problem of shortage of teachers in the college English teaching. But, there is also a challenge to introduce MOOC to the college English teaching. This paper analyzes the challenge and revelation MOOC brings to college English teaching combined with the characteristics of MOOC, and points out that the role of teachers, students, and managers should be changed under the background of MOOC.
\end{abstract}

Keywords: MOOC, college English teaching, challenge and revelation

\section{Introduction}

As a massive open online course development mode, so far MOOC has set off a storm in global education circle just a few short years time in 2011, which is considered to be a big education innovation. The courses MOOC offers are the world's quality of school masters courses, which are transmitted to the audience by MOOC class platform. At the same time, MOOC attracted a lot of learners quickly with its free and high quality. Compared with traditional classroom teaching, MOOC mainly has three major characteristics and advantages, including large-scale, openness, and online learning. How to effectively carry out reformation and promote the development of their own for college English teaching under the background of MOOC? The author will discuss the challenge and revelation MOOC brings to the college English teaching.

\section{The Challenge MOOC Brings to the College English Teaching}

\section{Teaching Mode}

In traditional college English teaching mode, teachers are dominant, while the student is the recipient of knowledge, and teaching process makes the textbook as the center paying attention to the knowledge and skills training for students in class. Actually, the center of this kind of teaching mode is the teacher, emphasizing the authority of teachers, but the participation and enthusiasm of students are restricted, also difficult to learn actively; making the teaching material as the center will imprison the student's thought, which is not conducive to the cultivation of students' divergent thinking and creative thinking; making the classroom as the center will be not conducive to the improvement of the cultivation of the students individualized and autonomous learning ability.

XU Li-mei, lecturer, Ph.D. candidate, Foreign Languages College, Changchun University.

TONG Li-jun, associate professor, master, Foreign Languages College, Changchun University. 
Different from traditional courses, the content of MOOC is not prepared, but the aggregation of curriculum resources on the Internet, and based on the different learning objectives, students can restructure learning content through various communication reports or web page.

At the same time, students can also communicate with teachers and classmates to share all sorts of study resource in addition to watching the teacher' online tutorials; and learners can also interact with teachers and classmates to discuss through a variety of social network and platform. Besides, they can manage to set up online study group review course and share notes, or discuss learning problems or topics.

\section{Teaching Content}

The traditional college English teaching regards textbook as the center, and makes the interpretation of the text as the main task in class. The basic parts of the teaching process for teachers in class include text import, text structure analysis, difficult words, and sentences express appreciation, writing method, etc. When interpreting the text, even the teacher adds a small amount of oral practice mainly limited in words and sentences; students have little chance of coherent expression. Besides, the teaching content is too drab and poor, so student can only study seven or eight articles and some related background knowledge in a semester, which will hinder the student's field of vision, causing the students narrow knowledge and small vocabulary. This phenomenon is unfavorable whether to raise the level of English or the expansion of knowledge and the comprehensive improvement of quality. In the mode of MOOC, students have no textbooks, and the teacher designs and explains the course according to his own ideas and understanding of the course. Apart from that, students can choose large online aggregation of curriculum resources through MOOC platform according to their interests and actual situation in class. Compared with the traditional college English teaching, the teaching content of MOOC is very rich, and the amount of information is also very large.

\section{The Teacher}

In the traditional teaching mode, teachers dominate the classroom teaching, but there are also a lot of problems by teachers themselves, such as backward teaching concept, monotonous teaching content, and old teaching methods. SHU Ding-fang (2014) pointed out that many English teachers' teaching idea were behind, not focusing on the new foreign language teaching theory; the classroom teaching still makes language knowledge as the main line; teacher's explanation is given priority to, while students are just in a passive to accept the position, ignoring the interaction between teachers and students. Besides, the purpose of classroom teaching is not to cultivate students' autonomous learning ability, but to cultivate the students' examination techniques. This kind of teaching mode cannot see the specific goals to achieve by teaching these materials, neither can see the specific requirements for the students, but it still regards the language knowledge as the main teaching goal, which usually makes classroom language practice beyond real life and the cognitive characteristics of students limited in skills training. The related subjects, knowledge content, and the students' knowledge system are lack of organic connection with other related disciplines. There are so many teachers lack of innovation in teaching process. Although some teachers would arrange a certain amount of time to let students practice a few language structure, because of the student number, less training time, and other reasons, teacher cannot provide effective guidance and supervision generally, and such student group activities lack effect. The existing teaching environment, especially the teaching goal is under the background of examination-oriented; teachers tend to lack 
the innovation power.

\section{The Revelation MOOC Brings to the College English Teaching}

\section{Teaching Content}

College English teaching should not be confined to the content of the teaching material and the text. Learning a language means learning a culture. Relying on a few text explanation alone, every semester is not enough to fully improve the students' English level and broaden students' scope knowledge, even strengthen students' understanding of the target language culture and civilization, which is far from the ideal goal of English teaching. According to the "College English Curriculum Requirements" (hereinafter referred to as the "Teaching Requirements") promulgated by education department in 2007, the overall objective of college English course is to improve students' English comprehensive application ability, autonomous learning ability, cross-cultural communication ability, and comprehensive cultural quality. Teachers can develop teaching task and content according to the "Teaching Requirements" combining the actual English level of students. College English course generally includes general and special use English: The former is about the western culture, political system, philosophy, news and events, science and technology innovation, entertainment, leisure, and other party; and the later includes academic English, professional and academic English, and so on.

\section{Teaching Methods}

Teachers should adopt the way of flip classroom teaching, and the flip classroom refers to adjusting the time inside and outside the classroom. Thus students can finish learning the required information online actively based on projects or tasks in the class, and teachers no longer take up a lot of class time to teach, but inspect the completed situation of the project or task for students and discuss the related issues, in order to improve the students' learning enthusiasm and promote their personalized learning. While, the popularity of the Internet and the emergence of MOOC platform provide a condition for flip class. The teaching content of teachers is no longer confined to the teaching material and text, assigning learning tasks, while students collect data through the network and MOOC platform preparing to complete the task. At last, students report their completion of the task to teachers and discuss the topic of task during class. In this process, the role of the teacher is very important; he needs to design tasks meeting with the "teaching requirements" and the level and interest of student; these tasks include oral and written expression, whose difficulty must be appropriate, otherwise, students will be too difficult or too easy to lose interest during completing the task. Besides, it is necessary for teachers to give students the used web sites and MOOC platform to carry out the tasks, so as to help them make a target and avoid unnecessary time waste. Teachers should make targeted feedback when students reporting the completion situation of tasks in the classroom to make students truly understand their learning effect, thus continuously improve their study in the later. Students also are the main body in this process; they complete the learning task by actively collecting data, sorting data, reporting results, and discussing. In this process, students do not have to follow the traditional teaching mode to passively accept knowledge, but initiatively learn and input with a clear goal through reorganization, digestion, report, and output, which can fully improve their enthusiasm and the learning efficiency. 


\section{Evaluation System}

Change the traditional simple evaluation way of students, and adopt the combination of formative assessment and summative assessment. Because many tasks need to do for students throughout the course, including collecting data, sorting data after class, and reporting results, and discussing in class; it is obviously unreasonable only to evaluate the performance of the students throughout the semester in the final examination. Formative evaluation not only emphasizes the students' classroom performance, but also takes a fancy to the students' learning activities. Evaluation is not only the appraisal of students' task completion, but also a means to motivate students and to improve the learning effect. Besides, it can also strengthen the interaction between teachers and students and arouse the learning enthusiasm of students, thus timely help students understand their learning effect and adjust learning strategies.

\section{The Role Change of Teachers, Students, and Managers Under the Background of MOOC}

In the whole teaching process, the role of teachers, students and managers must change to adapt to the new teaching mode. First of all, teachers should change ideas, change their own leading position from the center of the classroom and transformation to the designers and participants in the classroom. In traditional teaching mode, teachers have absolute dominance, and their teaching costs most of the class time, while in the new teaching mode, teachers should act as a guide and player in the classroom, helping students to better complete the task and strengthen the subject consciousness of the students. Secondly, students should also come out in the traditional classroom model, not play as passive recipients of knowledge any more, but as active seekers of knowledge. What they should do is to collect information carefully, to learn autonomously in class, and to be the main real body and owner of class. At the same time, students should also report the learning outcomes and communicate with teachers and schoolmates. Initiative to mobilize up, naturally the learning efficiency would be improved. In addition, the college managers should also change concept, not having been constrained by the inherent mode and outline of teaching, which would make restrictions to classroom teaching. They should give full freedom to the teacher's teaching, help the teacher realize development under the background of MOOC, and continuously explore new teaching methods and teaching mode. According to the actual needs, college needs to establish a new and more scientific teacher evaluation system and appraisal system, so as to ensure and promote the improvement of teachers' creativity and enthusiasm with these good systems.

\section{Conclusion}

Although the time of MOOC is not long, but it has caused a great impact and challenge to traditional classroom teaching, that is to say the teaching mode of MOOC is a subversion of traditional teaching concept. College English teaching in China should take advantage of this opportunity to the traditional teaching method to make further reflection, and think about how to make use of MOOC resources and teaching concepts to promote the college English teaching reform.

\section{References}

Dawkins , R. (1976). The selfish gene. New York: Oxford University Press.

Ellis, R. (2005). Principles of instructed language learning. System, 33(2), 209-224. 
Higher Education Department. (2007). Curriculum requirements of the ministry of education college English. Beijing: Foreign Language Teaching and Research Press.

SHU, D. F. (2014). Teaching problems and some research topics in the foreign language classroom. Foreign Language Teaching and Research, 446-455.

SHU, D. F., \& ZHUANG, Z. X. (2008). Modern Foreign Language Teaching. Shanghai: Shanghai Foreign Language Education Press.

WEN, Q. F. (2014). Output and input to hypothesis : The theory try of constructing university foreign language classroom teaching. China's Foreign Language Education, 3-11.

WU, Y. Q. (2008). Meme theory research in China nearly recent five years. Journal of Fuzhou University, 81-84.

YANG, X. Y. (2013). The review of west research about foreign language classroom process. Foreign Teaching, 34-36. 